\title{
Comparative phytochemical and in vitro antimicrobial activities of the leaf extracts of two medicinal plants growing in North-East, Nigeria
}

\author{
Hamidu Usman*, Muhammad Awwal Tijjani, Abdulkarim Hassan, Zainab Babagana Aji \\ Department of Chemistry, University of Maiduguri, P.M.B. 1069 Maiduguri, Nigeria
}

\section{ART I C L E IN F O}

Article Type:

Original Article

\section{Article History:}

Received: 6 July 2017

Accepted: 18 December 2017

\section{Keywords:}

Antimicrobial activity

Phytochemical evaluation

Herbal medicine

Medicinal plants

Punica granatum

Waltheria indica

\begin{abstract}
A B S T R A C T
Introduction: The use of plants as medicine is as old as chemistry and common to all societies including the African, notably some parts of Northern Nigeria. Infectious diseases are among the causes of mortality and morbidity in rural areas endemic with hygienic problems in most developing countries including Nigeria. Two plant species with similar ethnomedical reports from different families were used in this study against some microorganisms. Their phytochemicals were also evaluated.

Methods: The leaf samples of Punica granatum and Waltheria indica were prepared and independently extracted with $80 \%$ methanol using maceration technique. The extracts were concentrated to dryness at reduced pressure and then subjected to phytochemical evaluation. Antimicrobial activities were evaluated using hole-in-plate disc diffusion technique.

Results: The phytochemical results of both extracts revealed the absence of anthraquinones. However, both extracts showed the presence of cardenolides, cardiac glycosides, flavonoids, saponins, tannins and terpenoids; while alkaloids were found in W. indica. The antimicrobial susceptibility study showed dose-dependent pattern with the highest dose ( $80 \mathrm{mg} / \mathrm{hole}$ ) showing inhibition zone of $23.67 \pm 0.47$ and $23.33 \pm 0.47 \mathrm{~mm}$, respectively by $P$. granatum and $W$. indica against Streptococcus pyogenes while at $20 \mathrm{mg} / \mathrm{hole}$ inhibition was noted as $8.67 \pm 0.47$ and $7.00 \pm 0.00 \mathrm{~mm}$ against Escherichia coli for $P$. granatum and $W$. indica, respectively.

Conclusion: The findings of this study scientifically support the use of $P$. granatum and $W$. indica in folklore medicine for the cure of infections by microbes.
\end{abstract}

Implication for health policy/practice/research/medical education:

Waltheria indica showed phytochemicals like cardenolides, cardiac glycosides, flavonoids, saponins, tannins, and terpenoids. However, alkaloids were found in only $W$. indica. The extracts showed dose-dependent broad spectrum antimicrobial activities against the test microorganisms which could be attributed to the secondary metabolites present. Hence both plants might be used as a natural source for preparation of new drugs.

Please cite this paper as: Usman H, Tijjani MA, Hassan A, Aji ZB. Comparative phytochemical and in vitro antimicrobial activities of the leaf extracts of two medicinal plants growing in North-East, Nigeria. J Herbmed Pharmacol. 2018;7(2):61-67. doi: 10.15171/jhp.2018.11.

\section{Introduction}

Traditional medical practices use the knowledge and belief of involvement of natural products, spiritual therapies and some exercises applied singly or in combination with the cure of man (1). Historically, man has been using various plant parts in prevention and treatment of several diseases (2). In the early 20th century, traditional medicine was regarded as a practice employed by poor society. However, synthetic or biomedical drugs have been doubted by some developed countries; thus giving interest in natural medicines or therapies (3). A plant becomes medicinal only when its biological activity has been ethnomedically reported or scientifically established (4). Depending on the usage, folk medicine may be regarded as traditional medicine, alternative medicine, indigenous medicine, or natural medicine (5). Traditionally, plants have been used as a source for treatment of diseases through secondary metabolites which play a significant role as medicines, 
flavouring and recreational drug in different parts of the world whose use contributes immensely to the enhancement of primary health care delivery $(6,7)$.

The plant Punica granatum Linn. (Lythracea) commonly called pomegranate in English, "Anar, Anar-ke-per" in Hindi, "Anar" in Urdu, "Punjabi and "Rooman" in Arabic originated from Iran to the Himalayas in Northern India and found widely distributed the Mediterranean region of Asia, Africa and Europe (8). The rind of the fruit and the bark of the tree are used in the treatment of diarrheoa, dysentery and intestinal parasites, for nose and gum bleeds, toning skin and treating hemorrhoids in ancient Ayurvedic traditional medicine. Its juice is employed as an eye drop to stop the development of cataracts; the seeds and rind are also used as contraceptive and abortifacient. The most abundant phytochemicals in P. granatum juice are polyphenols, including the hydrolysable tannins or ellagitannins (9), condensed tannins (10), catechins, gallocatechins and prodelphinidins. The antioxidant property of Punica granatum has been reported, previously (11).

Waltheria indica Linn. (Malvaceae) is one of the species of flowering plants in the mallow family which have a tropical distribution. W. indica (sleepy morning) commonly called velvet leaf, marsh-mallow, monkey bush, boater bush, leather coat, among other names (12); is abundantly found in West Africa (13). In Nigeria, the plant is locally known as "hankufa" or "hankubah" in Hausa, "kori kodi" in Yoruba, kafafi" in Fulani", and "efu$a b e$ " in Nupe languages (14). W. indica is a plant that has attracted medicinal interest because of its applications in traditional medicine to treat ailments employed as infusion or decoction where febrifugal, purgative, emollient, tonic, analgesic and astringent action is sought (12). The plant is used by Hausas of Northern Nigeria for the treatment of skin diseases, impotency and infertility. It is also used as an aphrodisiac and children's medicine at birth and during teething period (15).

It has been established that infectious diseases especially microbial type constitute a large number of health problems, especially in the developing countries. There is high proliferation of resistance to antimicrobial agents which not only does it result from poor quality drugs manufactured, patient non-compliance and irrational use of antimicrobial agents, but also could be due to mutations within the microbial flora (16). Therefore, the aim of this research was to ascertain the ethnomedical claim by the local populace and to compare the efficacy between the two plant extracts which are locally used here in the treatment of infectious diseases.

\section{Materials and Methods}

Sample collection and identification

Fresh leaf sample of $P$. granatum was collected from Gabanni-Babaji Village, Fika Local Government area, Yobe State while W. indica was collected from Wadiya
Village, Maiduguri Metropolitan Council, Borno State. The plant samples were identified by a taxonomist at Botany section, Department of Biological Sciences, University of Maiduguri, Nigeria. Both plant samples were air-dried at room temperature and freed from twigs and dirt and then ground into coarse-powdered form with wooden mortar and pestle.

\section{Extraction procedure}

Two hundred and fifty grams of the powdered plant materials of each sample were independently extracted for 120 hours using $80 \%$ methanol in extraction bottle employing maceration technique. The extractives were filtered differently using Whatman No.1. The filtrate was poured into evaporating dish to dryness at reduced temperature and pressure and then kept in a desiccator until use.

\section{Phytochemical screening}

Phytochemical screening for the presence or absence of the secondary metabolites such as alkaloids, anthraquinones, cardenolides, cardiac glycosides, flavonoids and saponins were carried out according to the standard procedures as described previously (17-21).

Test for alkaloids

Half gram of the extract was stirred with $5.0 \mathrm{~mL}$ of $2 \mathrm{M}$ aqueous hydrochloric acid in a steam bath. $1.0 \mathrm{~mL}$ each of the filtrate was separately treated with few drops of Mayer's reagent, Drangendorffs' reagent and Wagner's reagent; appearance of buff-coloured precipitate, orangered precipitate and a dark-brown precipitate indicated the presence of alkaloid (21).

Test for tannins

Half $g$ of the plant extract was dissolved in $10 \mathrm{ml}$ of distilled water and filtered. To $2 \mathrm{ml}$ of the filtrate, few drops of $1 \%$ ferric chloride solution was then added. The occurrence of blue-black, green or blue-green precipitate colour indicates the presence of tannins (17).

Test for cardiac glycosides

Liebermann-Burchard's test

To $0.5 \mathrm{~g}$ of the extract, $2 \mathrm{~mL}$ of acetic anhydride was added. The mixture was cooled in an ice, and then conc. $\mathrm{H}_{2} \mathrm{SO}_{4}$ was added carefully. Colour development from violet to blue or bluish-green indicates the presence of steroidal ring (20).

\section{Salkowski's test}

To $0.5 \mathrm{~g}$ of the extract, $2 \mathrm{~mL}$ of chloroform was added; followed by conc. $\mathrm{H}_{2} \mathrm{SO}_{4}$ by the side of the test tube to form a lower layer. The appearance of reddish-brown or yellow colour at the interphase indicates the presence of a steroidal ring (20). 
Test for saponins

A small portion of the plant extract was added to distilled water $(20 \mathrm{~mL})$ in a $100 \mathrm{~mL}$ beaker, boiled and filtered. About $5 \mathrm{~mL}$ of the filtrate was shaken vigorously for about 5 minutes. Frothing which persists on warming indicated the presence of saponins (18).

Test for free anthraquinones

About $0.5 \mathrm{~g}$ of the plant extract was shaken with $10 \mathrm{~mL}$ of benzene and then filtered. Five milliliters of $10 \%$ ammonia solution was added to the filtrate. The resultant mixture was shaken. The appearance of pink, red or violent colour at the lower phase indicates the presence of anthraquinones (21).

\section{Test for combined anthraquinones}

To $0.5 \mathrm{~g}$ of the extract, $10 \mathrm{~mL}$ of aqueous $\mathrm{H}_{2} \mathrm{SO}_{4}$ was added and shaken and transferred while was hot. The filtrate was shaken with $5 \mathrm{~mL}$ of benzene. The benzene layer was separated and was added half its own volume with $10 \%$ ammonia solution. The presence of pink, red or violet colouration in the ammoniacal phase indicates the presence of combined anthraquinones (21).

\section{Test for flavonoids}

Ferric chloride test

To $0.2 \mathrm{~g}$ of the extract, $5 \mathrm{~mL}$ of water was added, boiled and filtered. To $2 \mathrm{~mL}$ of the filtrate, few drops of $10 \%$ ferric chloride were added. A green-blue or violet colouration indicates the presence of phenolic hydroxyl group (21).

\section{Shinoda's test}

About $0.2 \mathrm{~g}$ of the extract was dissolved in $5 \mathrm{~mL}$ of ethanol, warmed and then filtered. Few pieces of magnesium chips were added to the filtrate followed by few drops of conc. $\mathrm{HCl}$, a pink, orange or red to purple colouration indicates the presence of flavonoids (19).

\section{Lead acetate test}

Exactly $0.5 \mathrm{~g}$ of the extract was dissolved in $5 \mathrm{~mL}$ of distilled water. Tree milliliters of $10 \%$ lead acetate solution were added. The appearance of buff-coloured precipitate indicates the presence of Flavonoids (21).

\section{Test for terpenoids}

About $0.2 \mathrm{~g}$ of the extract was dissolved in $5 \mathrm{~mL}$ of ethanol. One milliliter of acetic anhydride was added, followed by addition of conc. $\mathrm{H}_{2} \mathrm{SO}_{4}$. The presence of terpenoids in the sample was detected as the colour changes from pink to violet (20).

Test for cardenolides

Keller-Killiani's test

Exactly $0.5 \mathrm{~g}$ of the extract was dissolved in $2 \mathrm{~mL}$ glacial acetic acid containing a drop of ferric chloride solution. One milliliter of conc. $\mathrm{H}_{2} \mathrm{SO}_{4}$ was added. The appearance of a brown ring at the interphase shows the presence of digitoxose sugar characteristic of cardenolides (21).

\section{Test for carbohydrates}

Molisch's test

Few drops of Molisch's reagent were added to $2 \mathrm{~mL}$ of the extract obtained by dissolving in distilled water. To this, 1 $\mathrm{mL}$ of conc. $\mathrm{H}_{2} \mathrm{SO}_{4}$ was added to the side of the test tube. The mixture was allowed to stand for 2 minutes and then diluted with $5 \mathrm{~mL}$ distilled water. Formation of red to dullviolet colour at the interphase of the two layers was taken as the positive test (21).

\section{Test for free reducing sugars}

Exactly $0.2 \mathrm{~g}$ of the extract was dissolved in $5 \mathrm{~mL}$ of distilled water and filtered. The filtrate was heated with $5 \mathrm{~mL}$ of equal volumes of Fehling's solution $\mathrm{A}$ and $\mathrm{B}$ formation of a red precipitate of cuprous oxide indicates the presence of reducing sugar's (21).

Test for combined reducing sugars

Exactly $0.2 \mathrm{~g}$ of the extract was hydrolyzed by boiling with $5 \mathrm{~mL}$ of dilute hydrochloric acid and filtered; the resulting filtrate was neutralized with sodium hydroxide solution. Few drops of Fehling's solution were added and then heated in a water bath for 2 minutes. Formation of reddish-brown precipitate of cuprous oxide indicates the presence of combined reducing sugars (21).

\section{Test organisms}

Three strains of gram-positive bacteria used include Bacillus subtilis, Staphylococcus aureus and Streptococcus pyogenes, Gram-negative were Escherichia coli, Klebsiella pneumoniae and Pseudomonas aeruginosa; while Candida albicans was the only fungal species used in this study. These organisms were clinical isolates obtained from Department of Veterinary Medicine, University of Maiduguri, Maiduguri, Nigeria.

Antimicrobial susceptibility test

The antimicrobial susceptibility test was carried out using the agar plate disc diffusion technique as described by National Committee for Clinical Laboratory Standards (22) and modified by Usman et al (23). The tests were carried out using a stock concentration of $400 \mathrm{mg} / \mathrm{mL}$ prepared by dissolving $4 \mathrm{~g}, 200 \mathrm{mg} / \mathrm{mL}$ prepared by dissolving $2 \mathrm{~g}$ and $100 \mathrm{mg} / \mathrm{mL}$ prepared by dissolving $1 \mathrm{~g}$ of the crude extract differently into $10 \mathrm{~mL}$ of sterile distilled water. Working volumes was $0.2 \mathrm{~mL}$ each of the concentrations prepared and then dispensed into each of the $6 \mathrm{~mm}$ bored holes to afford respectively 80, 40 and 20 $\mathrm{mg} /$ hole. After incubation, the average diameter of three readings of the clear zone around the hole was recorded as the measure of inhibitory level of the extract against the test bacteria and reported as mean \pm SEM. The dilution ratio for gram-positive bacteria and gram-negative 
bacteria was 1:1000 and 1:5000 respectively using peptone water (23).

Determination of minimum inhibitory concentration A serial dilution ranging from 100 to $6.25 \mathrm{mg} / \mathrm{mL}$ were made. The bacterial strain was cultured in nutrient broth as suspension; $5 \mathrm{ml}$ peptone water was then added. To the suspension, $5 \mathrm{ml}$ of each extract concentration was added to the nutrient broth cultures containing $1.0 \times 10^{7} \mathrm{CFU} / \mathrm{mL}$ which were seeded into each test tube and then incubated at $37^{\circ} \mathrm{C}$ for $18-24$ hours. Test tube with no turbidity was taken as the MIC value (24).

Determination of minimum bactericidal concentration Aliquots from the MIC studies were used for the MBC determination. To a solid nutrient agar, a bacterial streak of the suspension from the MIC test tube was made and the procedure repeated all through the required numbers of corresponding isolates. The isolated organism on the nutrient agar was incubated at $37^{\circ} \mathrm{C}$ for $18-24$ hours. After incubation, the plates were observed for bacterial growth; the lowest concentration of the extract required to kill microorganism was considered as the MBC value (24).

\section{Results}

The phytochemical screening and antimicrobial activities were conducted on the methanolic leaf extracts of $P$. granatum and $W$. indica. The results of phytochemical screening are presented in Table 1 while the results of antimicrobial susceptibility are shown in Table 2 . The minimum inhibitory concentrations (MICs) of the extracts are presented in Table 3; the results for the minimum bactericidal concentrations (MBCs) of the extracts are expressed in Table 4.

\section{Phytochemical screening}

The percentage extractive of $W$. indica was $11.43 \%$ and of P. granatum was $13.83 \% \mathrm{w} / \mathrm{w}$. Phytoconstituents found in these extracts were cardenolides, cardiac glycosides, flavonoids, saponins, tannins and terpenoids. However, only $W$. indica indicated the presence of alkaloids. More so, both extracts had not any anthraquinones (Table 1).

\section{Antimicrobial susceptibility}

The susceptibility pattern of the extract revealed that the highest activity for both extracts was found at the highest concentration of $80 \mathrm{mg} /$ hole with the DIZ values of $23.67 \pm 0.47$ and $23.33 \pm 0.47 \mathrm{~mm}$, respectively for $T$. avicceniodes and $W$. indica against $S$. pyogenes. However, the least activities were also recorded as $8.67 \pm 0.47$ and $7.00 \pm 0.00 \mathrm{~mm}$ inhibition zone against E. coli at $20 \mathrm{mg} /$ hole (Table 2).

\section{Minimum inhibitory concentration}

The minimum inhibitory concentration exhibited by T. avicceniodes was indicated as $12.5 \mathrm{mg} / \mathrm{ml}$ against $K$.
Table 1. Phytochemical analysis of crude leaf extracts of Punica granatum and Waltheria indica

\begin{tabular}{|c|c|c|c|}
\hline \multirow{2}{*}{ S/No. } & \multirow{2}{*}{ Phytochemical tests } & \multicolumn{2}{|c|}{ Plant species } \\
\hline & & P. granatum & W. indica \\
\hline \multirow[t]{3}{*}{1} & Test of alkaloids & & \\
\hline & Preliminary test for alkaloid & - & + \\
\hline & Confirmatory test for alkaloid & - & + \\
\hline \multirow[t]{2}{*}{2} & Test of free anthraquinones & - & - \\
\hline & Test for combined anthraquinones & - & - \\
\hline \multirow[t]{4}{*}{3} & Test of carbohydrates & & \\
\hline & Molisch's test & + & + \\
\hline & Test for combined reducing sugars & + & + \\
\hline & Test of free reducing sugars & - & - \\
\hline \multirow[t]{3}{*}{4} & Test for Cardiac glycosides & & \\
\hline & Liebermann-Burchard's test & + & - \\
\hline & Salkowski's test & - & - \\
\hline \multirow[t]{2}{*}{5} & Test for cardenolides & & \\
\hline & Keller-Killiani's test & + & + \\
\hline 6 & Test of saponins glycosides & + & + \\
\hline 7 & Test of tannins & + & + \\
\hline \multirow[t]{5}{*}{8} & Test for flavonoids & & \\
\hline & Ferric chloride test & - & + \\
\hline & Shinoda's test & + & + \\
\hline & Lead ethanoate test & + & + \\
\hline & Sodium hydroxide test & - & + \\
\hline 9 & Test of terpenoids & + & + \\
\hline
\end{tabular}

Key: + = Present, - = Absent

pneumonia, $P$. aeruginosa and Candida albicans; while $W$. indica showed inhibition at the same concentration of 12.5 $\mathrm{mg} / \mathrm{mL}$ against $S$. pyogenes (Table 3).

Minimum bactericidal concentration

The results for the minimum bactericidal concentration revealed that the $\mathrm{MBC}$ value of $25.0 \mathrm{mg} / \mathrm{ml}$ was exhibited by both extracts while $W$. indica was comparatively effective showing MBC value of $12.5 \mathrm{mg} / \mathrm{mL}$ against $P$. aeruginosa and C. albicans (Table 4).

\section{Discussion}

The results of phytochemical screening of leaf extracts of $P$. granatum and Waltheria indica indicate the absence of anthraquinones in P. granatum as well as in W. indica which corroborated to the earlier report by Mohammed et al (15) that no parts of the plants showed the presence of anthraquinones. However, both extracts revealed the presence of cardenolides, cardiac glycosides, flavonoids, saponins, tannins, and terpenoids. Alkaloids were only present in $W$. indica as reported previously (15). These classes of compounds have been reported to be a remedy against many pathogenic consequences and hence, explain their use traditionally for the treatment of different kinds of diseases (25). Secondary metabolites like tannins, terpenoids, alkaloids, and flavonoids have been reported to have in vitro antimicrobial properties $(26,27)$.

Table 2 shows the results obtained from the antimicrobial evaluations of the leaf extracts of $P$. granatum and $W$. indica. The susceptibility pattern at concentrations of 
Table 2. Antimicrobial susceptibility of the leaf extracts of Punica granatum and Waltheria indica at different concentrations

\begin{tabular}{|c|c|c|c|c|}
\hline \multirow{2}{*}{ Microorganisms } & \multirow{2}{*}{ Extract } & \multicolumn{3}{|c|}{ Concentration of the extract/diameters inhibition zone $(\mathrm{mm})$, mean \pm SEM } \\
\hline & & $80 \mathrm{mg} / \mathrm{hole}$ & $40 \mathrm{mg} / \mathrm{hole}$ & $20 \mathrm{mg} / \mathrm{hole}$ \\
\hline \multirow[t]{2}{*}{ Bacillus subtilis } & P. granatum & $18.67 \pm 0.47$ & $14.67 \pm 0.47$ & $11.00 \pm 0.47$ \\
\hline & W. indica & $17.00 \pm 0.00$ & $13.00 \pm 0.00$ & $9.33 \pm 0.47$ \\
\hline \multirow[t]{2}{*}{ Staphylococcus aureus } & P. granatum & $13.67 \pm 0.47$ & $10.00 \pm 0.00$ & $11.33 \pm 4.71$ \\
\hline & W. indica & $17.67 \pm 0.47$ & $13.67 \pm 0.47$ & $10.00 \pm 0.00$ \\
\hline \multirow[t]{2}{*}{ Streptococcus pyogenes } & P. granatum & $23.67 \pm 0.47$ & $18.33 \pm 0.47$ & $14.00 \pm 0.00$ \\
\hline & W. indica & $23.33 \pm 0.47$ & $18.67 \pm 0.47$ & $14.33 \pm 0.47$ \\
\hline \multirow[t]{2}{*}{ Escherichia coli } & P. granatum & $16.67 \pm 0.47$ & $11.67 \pm 0.47$ & $8.67 \pm 0.47$ \\
\hline & W. indica & $12.00 \pm 0.00$ & $9.00 \pm 0.00$ & $7.00 \pm 0.00$ \\
\hline \multirow[t]{2}{*}{ Klebsiella pneumoniae } & P. granatum & $17.00 \pm 0.00$ & $12.67 \pm 0.47$ & $9.33 \pm 0.00$ \\
\hline & W. indica & $14.66 \pm 0.47$ & $10.66 \pm 0.47$ & $7.33 \pm 0.47$ \\
\hline \multirow[t]{2}{*}{ Pseudomonas aeruginosa } & P. granatum & $21.67 \pm 0.47$ & $17.67 \pm 0.47$ & $14.00 \pm 0.00$ \\
\hline & W. indica & $18.00 \pm 0.00$ & $14.00 \pm 0.00$ & $10.33 \pm 0.47$ \\
\hline \multirow[t]{2}{*}{ Candida albicans } & P. granatum & $19.67 \pm 0.47$ & $16.33 \pm 0.47$ & $12.33 \pm 0.47$ \\
\hline & W. indica & $18.00 \pm 0.00$ & $14.33 \pm 0.47$ & $10.67 \pm 0.47$ \\
\hline
\end{tabular}

Table 3. Minimum inhibitory concentrations (MICs) of the crude leaf extract of Punica granatum and Waltheria indica

\begin{tabular}{|c|c|c|c|c|c|c|}
\hline \multirow[b]{2}{*}{ Microorganisms } & \multirow[b]{2}{*}{ Extract } & \multicolumn{5}{|c|}{ Concentration $(\mathrm{mg} / \mathrm{mL})$} \\
\hline & & 100.0 & 50.0 & 25.0 & 12.5 & 6.25 \\
\hline \multirow[t]{2}{*}{ Bacillus subtilis } & P. granatum & - & $-*$ & + & + & + \\
\hline & W. indica & - & $-*$ & + & + & + \\
\hline \multirow[t]{2}{*}{ Staphylococcus aureus } & P. granatum & $-*$ & + & + & + & + \\
\hline & W. indica & - & - & $-*$ & + & + \\
\hline \multirow[t]{2}{*}{ Streptococcus pyogenes } & P. granatum & - & $-*$ & + & + & + \\
\hline & W. indica & - & - & - & $-*$ & + \\
\hline Escherichia coli & P. granatum & - & - & $-*$ & + & + \\
\hline Klebsiella pneumonia & P. granatum & - & - & - & $-*$ & + \\
\hline \multirow[t]{2}{*}{ Pseudomonas aeruginosa } & P. granatum & - & - & - & $-*$ & + \\
\hline & W. indica & - & - & $-*$ & + & + \\
\hline \multirow[t]{2}{*}{ Candida albicans } & P. granatum & - & - & - & $-*$ & + \\
\hline & W. indica & - & - & $-*$ & + & + \\
\hline
\end{tabular}

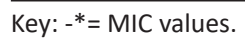

Table 4. Minimum bactericidal concentrations (MBCs) of the crude leaf extract of Punica granatum and Waltheria indica

\begin{tabular}{|c|c|c|c|c|c|c|}
\hline \multirow{2}{*}{ Microorganisms } & \multirow{2}{*}{ Extract } & \multicolumn{5}{|c|}{ Concentrations (mg/mL) } \\
\hline & & 100.0 & 50.0 & 25.0 & 12.5 & 6.25 \\
\hline \multirow{2}{*}{ Bacillus subtilis } & P. granatum & - & $-* *$ & + & + & + \\
\hline & W. indica & - & $-* *$ & + & + & + \\
\hline \multirow{2}{*}{ Staphylococcus aureus } & P. granatum & $-* *$ & + & + & + & + \\
\hline & W. indica & - & $-* *$ & + & + & + \\
\hline \multirow{2}{*}{ Streptococcus pyogenes } & P. granatum & - & - & $-* *$ & + & + \\
\hline & W. indica & - & - & $-* *$ & + & + \\
\hline Escherichia coli & P. granatum & $-* *$ & + & + & + & + \\
\hline Klebsiella pneumonia & P. granatum & - & $-* *$ & + & + & + \\
\hline \multirow{2}{*}{ Pseudomonas aeruginosa } & P. granatum & - & $-* *$ & + & + & + \\
\hline & W. indica & - & - & $-* *$ & + & + \\
\hline \multirow{2}{*}{ Candida albicans } & P. granatum & - & $-* *$ & + & + & + \\
\hline & W. indica & - & - & -** & + & + \\
\hline
\end{tabular}

Key: -** = MBC values. 
$80 \mathrm{mg} /$ hole of the extract of $P$. granatum and $W$. indica respectively had $23.67 \pm 660.47$ and $23.33 \pm 0.47 \mathrm{~mm}$. The least activity was recorded at the lowest dosage of $20 \mathrm{mg} /$ hole with $8.67 \pm 0.47$ and $7.00 \pm 0.00 \mathrm{~mm}$ against E. coli for P. granatum and W. indica respectively. Generally, the activities due by P. granatum were considerably higher than that exhibited by $W$. indica. These observations could not be unrelated to the components as well as compositions of the secondary metabolites, even though they almost contained similar phytoconstituents. Moreover, researches have demonstrated the antimicrobial activities of tannins, flavonoids and saponins (28). It was noticed that the only point where $W$. indica exhibited higher activity than $P$. granatum was against $S$. aureus. The activities against gram-negative, gram-positive as well as fungal species corroborated to the earlier findings which revealed that extractives from the plant were capable of inhibiting these groups of microorganisms. These antimicrobial activities against the test microorganisms may be indicative of the presence of broad spectrum antibiotics in both extracts (29).

The zone of inhibition produced by most antibiotic discs against some of the organisms was found to be greater in relation to those activities produced by most organisms under study though not statistically compared to those produced by the extracts. However, the diameters of antibacterial activity zones of inhibition $\geq 10 \mathrm{~mm}$ around the 21 petri dish were considered active (28). The higher activities presented by $P$. granatum could not be unrelated possibly to the concentrations of the phytoconstituents since both had similar compounds.

Punica granatum showed high MICs of $12.5 \mathrm{mg} / \mathrm{ml}$ against three organisms (Klebsiella pneumoniae, Pseudomonas aeruginosa, and C. albicans). W. indica on the other hand exhibited good activity against Streptococcus pyogenes. Higher MBCs were observed for both extracts against $S$. pyogenes at $25.0 \mathrm{mg} / \mathrm{ml}$ which coincide with the work of Deshi et al (30). More so, $W$. indica had the MBC of 25.0 $\mathrm{mg} / \mathrm{mL}$ on C. albicans and Pseudomonas aeruginosa.

\section{Conclusion}

In conclusion, these comparative studies have revealed the potency of each of the plant towards the test microorganisms studied. Although the overall susceptibility was shown by $P$. granatum but $\mathrm{MBC}$ value further expressed that $W$. indica had a very good bactericidal value on C. albicans, $P$. aeruginosa and also on $S$. pyogenes. Therefore, concurring to the earlier findings, it can be surmised that the extracts from $W$. indica can be said with little reservation that it can stand as a choice for the treatment of disease condition afflicted by $S$. pyogenes.

\section{Acknowledgements}

The authors wish to acknowledge the technical assistant rendered by Alh. I.A. Gulani.

\section{Authors' contributions}

All authors contributed to the study. $\mathrm{AH}$ and ZBA acquired data. HU prepared the drafting. HU and MAT revised it critically for important intellectual content and HU submitted it. All read and confirmed the article ready for publication.

\section{Conflict of interests}

The authors declared no competing interests exist.

\section{Ethical considerations}

Ethical issues (including plagiarism, misconduct, data fabrication, falsification, double publication or submission, redundancy) have been completely observed by the authors.

\section{Funding/Support}

This research was financially self-funded and supported by the authors.

\section{References}

1. Muazu J, Kaita AH. A review of traditional plants used in the treatment of epilepsy amongst the Hausa/Fulani tribes of northern Nigeria. Afr J Tradit Complement Altern Med. 2008;5(4):387-90.

2. Jamshidi-Kia F, Lorigooini Z, Amini-Khoei H. Medicinal plants: past history and future perspective. J Herbmed Pharmacol. 2018;7(1):1-7. doi: 10.15171/jhp.2018.01.

3. Ansari JA, Inamdar NN. The promise of traditional medicines. Int J Pharmacol. 2010;6(6): 808-12. doi: 10.3923/ ijp.2010.808.812.

4. Olaleye MT. Cytotoxicity and antibacterial activity of methanolic extract of Hibiscus sabdariffa. J Med Plant Res. 2007;1(1):9-13.

5. Kay MA. Healing with plants in the American and Mexican West. Tucson: University of Arizona press; 1996;19-20.

6. Croteau R, Kutchan TM, Lewis NG. Natural products (secondary metabolites). Biochemistry Molecular Biology Plants. 2000;24:1250-319.

7. Holetz FB, Pessini GL, Sanches NR, Cortez DA, Nakamura CV, Filho BP. Screening of some plants used in the Brazilian folk medicine for the treatment of infectious diseases. Mem Inst Oswaldo Cruz. 2002;97(7):1027-31.

8. Yasoubi P, Barzegar M, Sahari MA, Azizi MH. Total Phenolic Contents and Antioxidant Activity of Pomegranate (Punica granatum L.) Peel Extracts. J Agric Sci Technol. 2007;9(1):35-42.

9. Singh RP, Chidambara Murthy KN, Jayaprakasha GK. Studies on the antioxidant activity of pomegranate (Punica granatum) peel and seed extracts using in vitro models. J Agric Food Chem. 2002;50(1):81-6.

10. Kamal A, Khan MMR. Phytochemical evolution of some medicinal plants. Ind J Plant Sci. 2014; 3(4):5-8.

11. Chidambara Murthy KN, Jayaprakasha GK, Singh RP. Studies on antioxidant activity of pomegranate (Punica granatum) peel extract using in vivo models. J Agric Food Chem. 2002;50(17):4791-5.

12. Burkill HM. Useful plants of West Africa. 2nd ed. Vol. 5. 
London, UK: Royal Botanic Gardens, Kew; 2000:248-9.

13. Akobunda IO, Agyaklwa CW. The West African weeds. Ibadan: International Institute of Tropical Agriculture; 1998:406.

14. Hutchinson MJ, Dalziel JM. Flora of West Tropical Africa. Crown Agent for Oversea Government and Administration. London: Mill Bank; 1958:319.

15. Mohammed Z, Shok M, Ilyas N, Musa KY, Yaro AH. Analgesic activity of Waltheria indica Linn. Eur J Sci Res. 2007;16(1):6-9.

16. Denyer SP, Hodges NA, Gorman SP. Bacterial resistance to antibiotics and clinical uses of antimicrobial drugs. In: Hugo \& Russell's Pharmaceutical Microbiology. 5th ed. Blackwell Publishing; 2004:220-250.

17. Brain KR, Turner TD. The practical evaluation of phytopharmaceuticals. Bristol: Wright Science Technica; 1975.

18. Vishnoi NR. Advanced practical chemistry. GhaziabadIndia: Yikas Publication House, PVT Ltd; 1979:447-9.

19. Markham KR. Techniques of flavonoids identification. New York: Academic Press;1982.

20. Silva LG, Lee IS, Kinghorn DA. Special problem with the extraction of plants. In: Cannell RJP, ed. Natural Products Isolation. New Jersey, USA: Humana Press Inc; 1998:343364.

21. Trease GE, Evans WC. Pharmacognosy. 15th ed. London: Saunders Publishers; 2002.

22. NCCLS (National Committee for Clinical Laboratory Standards). Methods for Dilution Antimicrobial Susceptibility Tests for Bacteria that Grow Aerobically.
Villanova, PA: NCCLS; 1993.

23. Usman H, Haruna AK, Akpulu IN, Ilyas M, Ahmadu AA, Musa YM. Phytochemical and antimicrobial screenings of the leaf extracts of Celtis integrifolia Lam. J Trop Biosci. 2005; 5(2):72-76.

24. Pavithra PS, Janani VS, Charamathi KH, Indumathy R, Potala S, Verma RS. Antibacterial activity of plants used in Indian herbal medicine. Int J Green Pharm. 2010;4(1):22-8.

25. Usman H, Osuji JC. Phytochemical and in vitro antimicrobial assay of the leaf extract of Newbouldia laevis. Afr J Tradit Complement Altern Med. 2007;4(4):476-80.

26. Cowan MM. Plant products as antimicrobial agents. Clin Microbiol Rev. 1999;12(4):564-82.

27. Usman H, Abdulrahman FI, Ahmed LA, Kaita AH, Khan IZ. Antibacterial effects of cyanogenic glucoside isolated from the stem bark of Bauhinia rufescens Lam. Int J Biol Chem Sci. 2013;7(5):2139-50. doi: 10.4314/ijbcs.v7i5.30.

28. Olajuyigbe OO, Babalola AE, Afolayani AJ. Antibacterial and phytochemical screening of crude ethanolic extracts of Waltheria indica Linn. Afr J Microbiol Res. 2011;5(22):37604. doi: 10.5897/AJMR11.627.

29. Kostova I, Dinchev D. Saponins in Tribulus terrestris chemistry and bioactivity. Phytochem Rev. 2005;4(2):11137. doi: 10.1007/s11101-005-2833-x.

30. Deshi JJ, Barminas JT, Onwuka J, Dass PM, Maitera O, Muazu I. Antimicrobial efficacy of biosynthesized silver nanoparticles from different solvent extracts of Waltheria americana root. J Anal Sci Technol. 2016;7(1):23. doi: 10.1186/s40543-016-0104-7. 